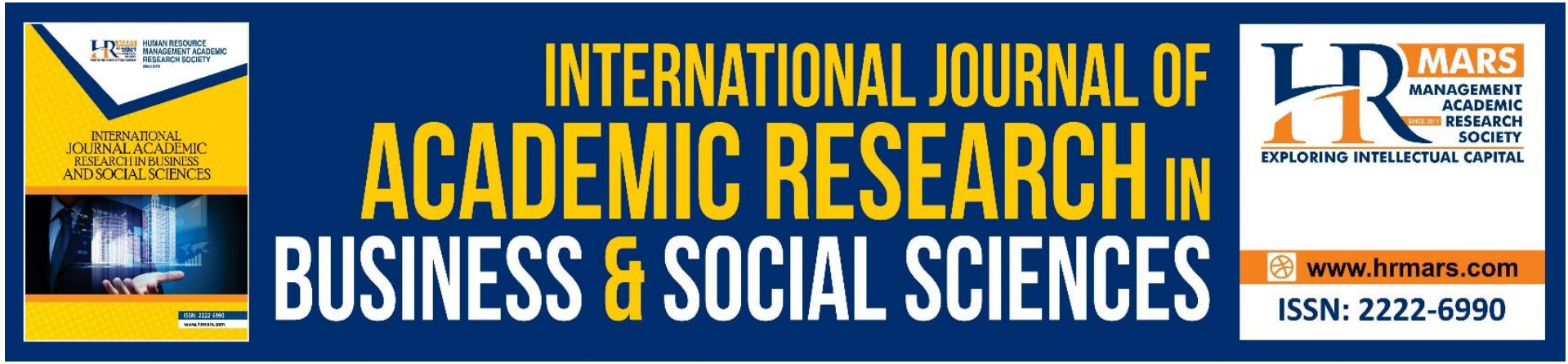

\title{
Old Malay Cities in Malay Historiographical Texts
}

\section{Siti Rabiatul Adawiah Jaffar, Hemamalani D/O Kunapalan}

To Link this Article: http://dx.doi.org/10.6007/IJARBSS/v11-i7/10586

DOI:10.6007/IJARBSS/v11-i7/10586

Received: 24 May 2021, Revised: 28 June 2021, Accepted: 09 June 2021

Published Online: 29 July 2021

In-Text Citation: (Jaffar \& Kunapalan, 2021)

To Cite this Article: Jaffar, S. R. A., \& Kunapalan, H. D. (2021). Old Malay Cities in Malay Historiographical Texts. International Journal of Academic Research in Business and Social Sciences, 11(7), 1239-1246.

Copyright: (C) 2021 The Author(s)

Published by Human Resource Management Academic Research Society (www.hrmars.com)

This article is published under the Creative Commons Attribution (CC BY 4.0) license. Anyone may reproduce, distribute, translate and create derivative works of this article (for both commercial and non-commercial purposes), subject to full attribution to the original publication and authors. The full terms of this license may be seen at: http://creativecommons.org/licences/by/4.0/legalcode

Vol. 11, No. 7, 2021, Pg. 1239 - 1246

http://hrmars.com/index.php/pages/detail/IJARBSS

JOURNAL HOMEPAGE

Full Terms \& Conditions of access and use can be found at http://hrmars.com/index.php/pages/detail/publication-ethics 


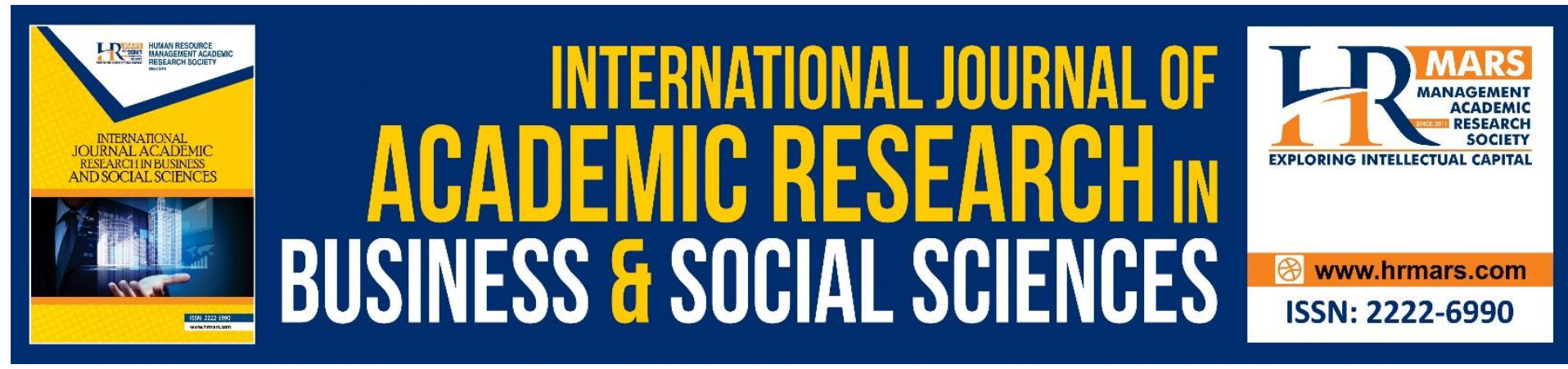

\title{
Old Malay Cities in Malay Historiographical Texts
}

\author{
Siti Rabiatul Adawiah Jaffar, Hemamalani D/O Kunapalan \\ Centre for Fundamental Studies, Management \& Science University, Shah Alam Malaysia \\ Email: sitirabiatul_adawiah@msu.edu.my, hemamalani@msu.edu.my
}

\begin{abstract}
Cities are treated as cultural artefacts that could showcase the achievements of a kingdom and highlight the civilisational elements of its people. At the same time, cities are posited as one example of Malay architecture, whose role in the everyday lives of the Malay society is examined. These observations are made upon the study of the role of cities from the architectural aspect, which includes layout and design, raw materials, and amenities that are featured in a city. In fact, cities are often the subject matter of traditional texts including Malay historiography. Informed by this approach, this article focuses on two objectives, namely identifying the design and building materials of old Malay cities and explaining the role of the city. Based on two historiographical texts, this study finds that old Malay cities were built using similar designs although other variables like building materials, time, and place of construction changed. The cities' infrastructure also made use of natural resources that were readily available in the surroundings. Additionally, the design and choice of building materials of old Malay cities play defining roles in turning the cities into fortress-cities and secure settlements, and even in the naming of the cities. It is hoped that this paper will contribute towards diversifying perspectives and source materials in the study of urban worldviews as well as enriching the cultural heritage of the Malay society.
\end{abstract}

Keywords: Early Malay Cities, Design, Building Materials, Role, Malay Historiographical Texts

\section{Introduction}

Depending on the situation and context, the word "city" could refer to several meanings. Among its definitions are fortress, defence stronghold, administrative centre, and place of living. Nasir (1990) is of the opinion that the word "city" is examined through the lens of its role in the lives of its inhabitants from the aspect of design, materials, and available amenities. For the Malay society, fortresses and administrative centres are generally defined as cities, which conform to Nasir's definition of the city as a fortress, a defence stronghold, or the administrative centre for the kings during the height of the Malay sultanate era. Nasir also states that Malays employs the word "city" rather liberally to mean all of the infrastructure mentioned before, including the cities mentioned in old Malay manuscripts (Nasir, 1990). In other words, the usage of the word "city" among Malays clearly refer to buildings and infrastructure that were established as fortresses, defence strongholds, administrative centres, and residential areas, depending on the context.

In this regard, the city is also a cultural heritage that showcases the excellence of a given kingdom. This could be seen in the old Malay kingdoms which presents the city as one factor 
when expounding the civilisational glories of its nation. In addition to that, Malay cities were also mentioned by foreign observers as one of the great achievements of the Malay society. Yusof (2014) cites Portuguese historians and philosophers like João de Barros, Damião de Góis, and Fernão Lopes de Castanheda who noted that Malay cities, particularly those in Melaka, were built in strategic locations, equipped with a variety of natural and manmade facilities, were of admirable size, and constructed using readily available natural materials. Overall, these features prove that Malay cities were important architectural monuments whose design and construction take many aspects of practical life into consideration.

\section{Problem Statement}

The existence of Malay cities in the Malay Sultanate era still dubious especially in the present (nowadays). This is because the Malay cities are focused now is the historic district, which contains built-colonial era building (Kosman et al., 2019). This is compounded by the destruction of the Malay cities during the colonial occupation. Even so, the study of Malay cities often mentioned in historical records or historical writing as the great majestic and powerful (Kosman et al., 2019). Although there are some of researchers who said Malay cities in the text are still rare and not much can be examined based on the written records and historical text (Harun et al., 2012). Meanwhile, the Malay cities can be explored through the old Malay text. This conforms with the opinion of Shahrum Bin Yub's exposition on the many functions of cities, which, according to him, are frequently mentioned in traditional works (Saud, 1981). In fact, the results of studies on Malay cities from the historical text are preserved and disseminated for future generations (Harun et al., 2012). Thus, this study can obviously be extended to the study of text analysis, based on records and narrative contained in the historical text. Furthermore, studies based on text analysis are said to be more effective than studies in other forms, as stated by Soebadijo (1974) states in relation to "information obtained from literature provides more information than information in other forms" (Soeratno, 2009).

The definition of city clearly shows the central role of cities that can be seen through their design and building materials (Nasir, 1990). In other words, the study of city is geared toward the architecture aspect and its role. Therefore, this article will discuss the architecture of the old Malay Cities as contained in Malay historiography, as history-oriented work, and explain the role of city based on the architecture, as written in the Malay historiography text.

\section{Study Objectives}

- To identify the design and building materials of old Malay cities from Malay historiographical texts.

- To explain the role of old Malay cities as mentioned in Malay historiographical texts.

\section{Research Methodology}

This study relies on library research for data collection by consulting primary and secondary sources like books, theses, and journal articles. Four steps are involved in the organisation of this article, which are selection, collection, analysis, and conclusion. In the data collection stage, the author examines manuscripts that were selected in accordance with the research objectives. Notes were made throughout the reading process, especially of sections that are relevant to the research questions. Following that, the data analysis stage focuses on analysing the information gathered during the first stage. Finally, an overall conclusion of the discussion is formulated. 


\section{Literature Review}

This study looks at old Malay cities from several angles. The research discovers that old Malay cities were designed to reflect the identity of the Malay society. Studies that examine the city of Melaka, for instance, show that its design was simple and featured the repetition of squares and rectangles in its layout (Mokhtar et al., 2019; Harun et al., 2014; Kosman et al., 2019). The foundation for all old Malay cities is said to be the same no matter where it was built (Kosman et al., 2019).

The design mirrors the philosophy that was the Malay worldview of that age. Interestingly, the fortress-city that was built by colonialists in Melaka is said to adopt the original design of old Malay cities (Harun et al., 2014). Similarly, building materials were made up of natural resources that could easily be obtained from the Malay Archipelago (Kosman et al., 2019). The case of the old Malay city of Kota Bharu shows the interconnectedness of many factors including the social, economic, and cultural life of its inhabitants (Mohamed, 2020).

On top of its material roles, these cities also fulfilled multiple functions including becoming a part of the identity of the place that they occupy as well as of the power that rules over them (Harun et al., 2019; Kosman et al., 2019). Other studies related to the cities are effort to give a new definition regarding Malay town that focuses on the Royal cities.

A study by Shukri et al (2018) gives a new definition of a Royal city regarding a city related to the community, a defensive city, and a Royal city "Istana kota" where the government is located. Through this study, the physical facilities available in the city contributes to the uniqueness of identity that should be preserved (Shukri et al 2018).

The other study also deals with other cities to identify the picture of the old Malay cities empirically. Ossen et al (2010) stated the importance of physical entities that exist to form of a traditional Malay city. Each entity involved has a role and impact on Malay cities. The establishment of Malay cities also received external influence but not thoroughly (Ossen et al, 2010). Next, the studies related to city as a symbol and its identity.

The study focuses on the Royal city, found that there are three significant characteristics that exist in the Royal Malay cities, called the King's palace, the Malay settlement known as the kampung and the traditional Malay fortification system. All the features are manufactured using Malay architecture, from high quality of local materials in order to fulfil the role of either literally or symbols that make up the identity of the Malay community (Samsudin et al., 2018).

\section{Analysis and Discussion}

\begin{tabular}{|c|l|c|c|}
\hline \multirow{2}{*}{ Text } & \multicolumn{1}{|c|}{ City } & \multicolumn{2}{c|}{ Design } \\
\cline { 3 - 4 } & & Fence & Walls \\
\hline \multirow{3}{*}{ Sulalatus Salatin } & Kota Gangga Negara & $/$ & $/$ \\
\cline { 2 - 4 } & Kota Biawak Busuk & $/$ & \\
\cline { 2 - 4 } & Kota Pagar Ruyung & $/$ & \\
\hline \multirow{2}{*}{ Misa Melayu } & Kota Pulau Indera Sakti & $/$ & \\
\cline { 2 - 4 } & Kota Tanjung Putus & & $/$ \\
\hline
\end{tabular}

Table 1: City design as mentioned in Sulalatus Salatin and Misa Melayu

The two selected texts, Sulalatus Salatin and Misa Melayu identify two types of cities, namely fenced in cities and walled cities. This shows that cities built by old Malay kingdoms revolve around the same layout regardless of the differences in location (Kosman et al., 2019). The fenced city seems to be the dominant design of old Malay cities, and this feature also plays a role in the naming of some cities like Kota Pagar Ruyung, which as indicated by its name, is a 
city whose enclosure is constructed using ruyung, which is the tough bark of the sago palm (Ahmad, 1979).

Two of the cities mentioned in the texts, Kota Gangga Negara and Kota Tanjung Putus, had walls built around them instead of fencing. In this category, the wall design is identified via three characteristics, which are the construction materials and technique-namely the embankment technique-which in turn culminates in the design of the walls. In fact, the design of this type of wall is referred to using the word "baiduri" in poetry, which probably does not mean a type of stone, but is a reference to "baluri", which is the walls of a city (Nasir, 1990). Therefore, the characteristics of a city's structures are also an indication of how the rest of the city was constructed.

\begin{tabular}{|l|l|c|c|c|}
\hline \multirow{2}{*}{ Text } & \multicolumn{1}{|c|}{ City } & \multicolumn{3}{c|}{ Material } \\
\cline { 3 - 5 } & & Stone & Soil & Wood \\
\hline \multirow{4}{*}{ Sulalatus Salatin } & Kota Langiu & $/$ & & \\
\cline { 2 - 5 } & Kota Pagar Ruyung & & & $/$ \\
\cline { 2 - 5 } & Kota Bijaya Negara & $/$ & & \\
\cline { 2 - 5 } & Kota Pasir Raja & & & $/$ \\
\hline \multirow{2}{*}{ Misa Melayu } & Kota Pulau Indera Sakti & & & $/$ \\
\cline { 2 - 5 } & Kota Tanjung Putus & $/$ & $/$ & \\
\hline
\end{tabular}

Table 2: Construction materials in old Malay cities according to Sulalatus Salatin and Misa Melayu

Generally, the raw materials used to build a city are extracted from natural resources that are found in the immediate surroundings. These include limestone from seashells, beeswax, egg whites, and wood. In the building of Malay cities, three primary materials were used: stones, soil mounds, and wooden stakes (Nasir, 1990). Wood was used because it was easily available and for its durability. Sulalatus Salatin mentions that the Kulim tree wood was chosen as one of the primary raw materials in constructing Kota Pasir Raja (Ahmad, 1979). The Kulim tree (Scorodocarpus borneensis) could easily be found in the Malay peninsula and is especially suitable for constructing buildings due to its hardness, heaviness, durability, fine texture, resistance to insects, and strong wooden fibres (Dumanauw, 2001: 22-23). Clearly, the ready availability and characteristics of the Kulim tree wood made it a natural choice as one of the best construction materials for traditional Malay cities (Jaffar et al., 2020).

Sometimes, these materials are used in combination with each other in order to produce stronger and more varied buildings. For example, the construction of Kota Tanjung Putus combines the use of stones and soil (Mohd, 1992). The Malays would employ certain techniques to construct buildings using these two materials. One of the methods they used was to construct the structures with stones initially, and then to spread and smooth over this base with dirt. Another method was to arrange stones on a soil embankment, and a third method was to create an embankment of stones over soil (Nasir, 1990). Kota Tanjung Putus, which, according to poetry, was built using stones-as referred to using the word "baiduri" and soil embankment-was constructed using the third method. Misa Melayu then mentions that the walls of Kota Tanjung Putus were built using natural materials and were erected along the strait cliffs, which shows that the purpose of construction was to protect the inhabitants within from environmental threats like coastal erosion (Mohd, 1992).

This goes to show that the Tanjung Putus city was built to provide security for the subject and government of the Perak Malay sultanate. The need for further security was also triggered the 
coming of the Dutch, who wanted to mine for tin in Perak. The establishment of Dutch tin mines in Tanjung Putus shows the assertion of the company's power in Perak, which in turn worried Sultan Iskandar Zulkarnain. In order to prevent further Dutch dominance on the tin mining trade, which could lead to the destruction of the Perak ruler's sovereignty and status, the sultan decided to build a city at Tanjung Putus as a form of defence and buffer between the Dutch settlement and the territories belonging to Perak (Mohd, 1992). The erection of the city walls as a defence edifice seems to achieve the desired effect, because the Dutch were observed to be displeased with the construction of this city. However, since the Dutch wanted to continue making profit from the tin trade, they were obliged to carry out transactions with the Perak sultanate, and therefore did not do anything to compromise the security of the Tanjung Putus city.

From the texts, it is obvious that the establishment of Kota Tanjung Putus brought about security and peace to the subjects and rulers of Perak. The building of cities can therefore be understood as one way for the Malay society to capitalise on the community's talents and on the natural resources at their disposal to establish settlements that can ensure the wellbeing of its inhabitants. The function of cities as fortresses is also mentioned by Sulalatus Salatin, which relays the story of the attack on Singapura by swordfish. The text highlights the decision to build a wall around Singapura using banana trees, whose tender stalks proved to be effective in halting the incoming swordfish since the latter's sharp, pointed bills immediately became stuck into the banana tree walls upon impact. Here, the raison d'être of Singapura's walls as a defence mechanism is proven (Ahmad, 1979).

\section{Conclusion}

An examination of old Malay cities also goes to show the intelligence of Malay societies in fulfilling their needs in conformity with the situation, ways of living, and the worldview of the community. The role of cities in the Malay civilisation has been narrated in historiographical texts like Sulalatus Salatin and Misa Melayu, which offer detailed accounts of the design and raw materials used to build Malay cities. In addition to that, both the design and raw materials chosen to betray the raison d'etre and the function of the city, therefore shaping the way "city" is defined in the Malay psyche. This study is also important to the community in helping to clarify the definition of Malay in addition to revealing to the community regarding its wealth of genre writing, which contains a various of information regarding Malay local wisdom. Furthermore, this study is also important for authoritative parties such as the Ministry of Tourism, Arts and Culture Malaysia in highlighting the cultural richness of Malaysian society which not only focuses on physical evidence, but also through written materials. This study is focused on a small part of the Malay historiography text, whereas there are many more text in the same genre that can be explored by researchers in view architecture and the role of the old Malay town that existed in the era of the Malay sultanate. Consequently, it is hoped that the study of cities in Malay societies will be diversified in terms of perspective and source material so that cities as a subject matter will gain more traction in popular discourse, and so that the scholarship on Malay cultural heritage could be further enriched. It is also hoped that the results of this study will contribute towards expanding the corpus of urban and city studies beyond fieldwork and incorporate more use of Malay historiographical texts. 


\section{References}

Ahmad, A. S. (1979). Sulalatus Salatin:(Sejarah Melayu)/Edited By A. Samad Ahmad. Dewan Bahasa Dan Pustaka.

Dumanauw, J. F. (2001). Mengenal Kayu. Yogyakarta, Indonesia: Penerbit Kanisius.

Yusof, H. (2017). Teknologi Kesultanan Melayu Melaka. Seremban, Negeri Sembilan: Cintai Publication.

Harun, M. N. S., \& Samsudin, M. (2019). Sejarah Bukit Puteri Sebagai Tapak Warisan Kebudayaan Semulajadi Di Negeri Terengganu. Jurnal Peradaban, 12, 103-118.

Harun, S. N., \& Jalil, R. A. (2014). The History And Characteristics Of Malay Early Towns In Peninsular Malaysia. Asian Journal Of Humanities And Social Studies (ISSN: 2321-2799), 2(03).

Jaffar, S. R. A., Sujud, A., \& Muhammad, S. J. N. (2020). Vernacular Architecture In Old Malay Building Through Malay Historiography. International Journal Of Academic Research In Business And Social Sciences, 10(2), 266-276.

Mokhtar, N. A., \& Kosman, K. A. (2019). Existence Of Melaka Malay (Fort) City Based On $A^{\prime}$ Famosa.

Nasir, A. H. (1990). Kota-Kota Melayu. Dewan Bahasa Dan Pustaka, Kementerian Pendidikan Malaysia.

Ossem, D. R., Aziz, Z. A. A., \& Idid, S. Z. A. (2010). The Islamic Malay Traditional Towns Learning Through The Attributes: Special Emphasis On Johor Bharu, Malaysia. 1st International Conference For Urban \& Architecture Heritage In Islamic Countries: Its Role In Cultural \& Economic Development, 23-28 May, Saudi Arabia.

Samsudin, N. A., Rosley, M., Raja Shahminan, R., \& Mohamad, S. (2018). Preserving The Characteristics Of Urban Heritage: An Insight Into The Concept Of Malaysian Royal Towns. Environment-Behaviour Proceedings Journal, 3(7), 277.

Saud, R. M. (1981). Kota-Kota Bersejarah Di Semenanjung Malaysia (Vol. 3). Jabatan Muzium. Shukri, S. M., Wahab, M. H., Amat, R. C., Taib, I., \& Rozaly, M. Z. M. (2018). Definition And Physical Attributes That Characterise Settings Of Malay Royal Towns in Malaysia. International Journal Of Engineering \& Technology, 7(3.9), 55-58.

Soeratno, S. C. (2009). "Peranan Naskhah Melayu Bagi Kehidupan Di Era Global." Melestarikan Manuskrip Melayu Warisan Agung Bangsa: Kumpulan Kertas Kerja Seminar Antarabangsa Manuskrip Melayu.

Fadzil, F. A. (2010). Rekonstruksi Rupa Bentuk Seni Bina Kota Pemerintahan Melayu Lama Daerah Perak Tengah. Thesis. Universiti Sains Malaysia

Ismail, P. S., \& Adam, M. (2020). Image And Identity Of Malay Royal Town In Malaysia. Planning Malaysia, 18(12).

Ismail, W. N. W., Jaâ, N. H., \& Harun, N. Z. (2018). Streets Of Royal Town: Exploring The Physical Character Of Traditional Street In The Malay Royal Town. The Journal Of Social Sciences Research, 991-996.

Jaffar, S. R. A., Muhammad, S. J. N., \& Kamarudin, K. (2017). Kawasan Sejarah Dari Perspektif Budaya Dalam Teks Sulalatus Salatin Sejarah Melayu Dan Misa Melayu. Rumpun Jurnal Persuratan Melayu, 5(1), 233-265.

Samsudin, N. A. (2014). The Physical Design Attributes of Traditional Malay Kampong in Kampung Tanjung Bunut, Kuala Terengganu. In 5th International Graduate Conference on Engineering, Science \& Humanity (pp. 19-21).

Shukri, S. M., \& Wahab, M. H. (2019). The Origin Of Malay Royal Town Concept Of Urban Form. 
Shukri, S. M., Wahab, M. H., \& Amat, R. C. (2020). Revealing Malay Royal Town Identity: Seri Menanti, Negeri Sembilan. In lop Conference Series: Earth And Environmental Science (Vol. 409, No. 1, P. 012034). lop Publishing.

Shukri, S. M., Wahab, M. H., Ibrahim, M. A., \& Rozaly, M. Z. (2017). Sd 26-Physical Characteristics Of A Public Square In Malay Royal Town. Sustainable And Resilient Cities: The Way Forward, 81. 